\title{
Michel Foucault on Methodius of Olympus (d.ca.311) in Les aveux de la chair: Patrick Vandermeersch's analysis contextualised
}

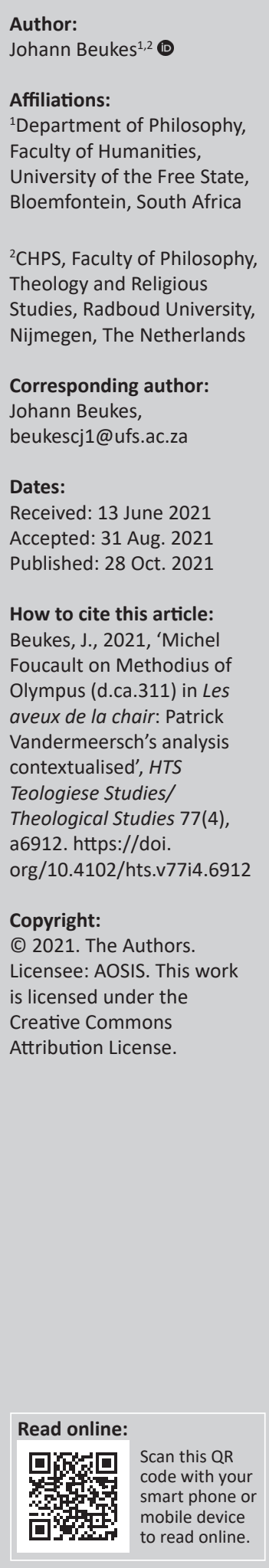

This article presents a contextualisation of Belgian philosopher and historian of psychiatry and sexuality, Patrick Vandermeersch's (1946-), unpublished analysis of French philosopher Michel Foucault's (1926-1984) interpretation of Methodius of Olympus' (d.ca.311) views on virginity and chastity, in Histoire de la sexualité 4 (Les aveux de la chair), published in February 2018 at Gallimard in Paris under the editorship of Frédéric Gros. The article contributes to the reception and the ongoing analyses of Les aveux de la chair by exploring Foucault's reading while highlighting both the importance of Vandermeersch's analysis and the sexological-historiographical significance of his broader oeuvre that spans over four decades. Vandermeersch shows that Foucault, as many other commentators of Methodius, did not substantially engage Methodius' explicit indebtedness and persistent references to Plato (already evident in the title Symposium but especially regarding the Phaedrus). Platonic homoeroticism is, according to Vandermeersch, as a consequence often too hastily, and therefore problematically, transposed on contexts of female virginity. Likewise, Foucault, when indicating already at the end of Histoire de la sexualité 2 (L'usage des plaisirs 1984), the particular relevance of homoeroticism in the development of Western sexuality, seemed to adhere to this transposition. Could 'beautiful boys' truly be transposed onto 'female virgins' without severe sexual-discursive complications? And could Methodius' encomium of virginity in any way be understood independent of his understanding of the 'resurrection of the body', with the integrity of its (virginised) sexual desire intact? These are among Vandermeersch's valid and challenging questions to both Foucault and his contemporary readership.

Contribution: Foucault's reading of the church- and desert fathers in Histoire de la sexualité 4 (Les aveux de la chair) impacts early Medieval philosophy, early Medieval history, church history, patristics, philosophy of religion, psychology of religion and sociology of religion. Since these proximate disciplines are drawn towards Foucault's text, they may well note its ongoing examinations. Foucault's direct impact on these disciplines is illustrated in Vandermeersch's significant analysis of Foucault's reading of Methodius in Les aveux de la chair. Vandermeersch's broader oeuvre in philosophy, theology, psychiatry, psychology, psychology of religion and the history of sexuality is concurrently contextualised as of ongoing contemporary importance for these disciplines.

Keywords: Katharina Bracht (1967-); Michel Foucault (1926-1984); Simon Goldhill (1957-); Histoire de la sexualité 4; Les aveux de la chair; Methodius of Olympus (d.ca.311); Phaedrus; Symposium; Patrick Vandermeersch (1946-); Jos van Ussel (1918-1976).

'[F]irst came the Pleasure... and then came all the Pain ...'

- Morrissey (2018:1:98-2:09)

\section{Foucault's Histoire de la sexualité 4 (Les aveux de la chair), 2018}

The objective of this article is twofold: firstly, to explore French philosopher Michel Foucault's (1926-1984) interpretation of Methodius of Olympus' (d.ca.311) views on virginity and chastity in his Histoire de la sexualité 4 (Les aveux de la chair; Foucault 2018), published in February 2018 at Gallimard in Paris under the editorship of Frédéric Gros (ed. 2018). This is done based on Belgian philosopher and historian of psychiatry and sexuality Patrick Vandermeersch's (1946-) unpublished analysis of Foucault's reading of Methodius (cf. Vandermeersch 2021:1-20). Concurrently, the article attempts to highlight the relevance and originality of this analysis as 
well as the significance of Vandermeersch's broader oeuvre in philosophy, theology, psychiatry, psychology, psychology of religion and the history of sexuality, one that spans over four decades (1968-2021) and is represented by 12 books (two of which as co-author), and an itemised list of 240 accredited articles, book chapters, book reviews and reports. ${ }^{1}$ The 'fourth' ${ }^{2}$ volume of Foucault's history of sexuality succeeds the three standing volumes published in 1976 and 1984 (Histoire de la sexualité 1-3 [Foucault 1976, 1984a, 1984b]). ${ }^{3}$ The edited and published version of the manuscript Les aveux de la chair ${ }^{4}$ comprises 426 pages (480 pages in

1.Vandermeersch's work is profoundly original and engages the deepest tenets of the Western psyche, from patristic history in the Latin West up to the psychoanalysis of Freud and Jung in the late 19th and early 20th centuries (cf. Vandermeersch 1991a, 2014:19-24, 2017b:55-63), as well as developments in related disciplines (such as psychology of religion) in the second half of the 20th century. The dissemination of Vandermeersch's work on the history of sexuality is therefore important beyond specialised domains of interest in philosophy and psychoanalysis. Since the bulk of his oeuvre has been published in Dutch, French and Spanish but very little of it in English the second part of this article provides an accessible overview of Vandermeersch's works (for the period 1968-2021) that relates directly to Foucault's history of sexuality. For a complete bibliography, consisting of 240 items for this period, see https://www. patrickvandermeersch.org/bibliography-2/ - viewed on 13 June 2021. After his retirement in 2008, Vandermeersch kept engaging his subject matter(s) tirelessly and retirement in 2008, Vandermeersch kept engaging his subject matter(s) tirelessly and
creatively - compare the relevant section in the bibliography. It should be noted at the creatively - compare the relevant section in the bibliography. It should be noted at the
outset that there is a complex 'triangular' hermeneutics involved here (Foucault reading outset that there is a complex 'triangular' hermeneutics involved here (Foucault reading
Methodius, Vandermeersch reading both Foucault and Methodius, and my reading of all Methodius, Vandermeersch reading both Foucault and Methodius, and my reading of all clear that I concur with Vandermeersch's reading, both of Foucault and Methodius. have no intention to advance an additional thesis to supplement Vandermeersch's analysis but only to bring his analysis to the fore in the English-speaking scholarship. Where additional comments beyond Vandermeersch's analysis are made, they will be indicated as mine and not as Vandermeersch's.

2.For an explanation about why I have up to now been reluctant to refer to Les aveux de la chair as the 'fourth' volume in the series Histoire de la sexualité, considered the publication of this unfinished manuscript as a polarising issue in the Foucault scholarship (cf. Beukes 2020b:16-24) and referred to the text via Gros as its editor rather than to Foucault as its 'author', see Beukes (2020a:2-7). Although this positioning is reviewed infra, the reasons for it remain unchanged: the text should namely not is reviewed infra, the reasons for it remain unchanged: the text should namely not without a proper account of its idiosyncratic development be regarded as the 'fourth'
volume of the series since it is an edited version of a manuscript, primarily based on volume of the series since it is an edited version of a manuscript, primarily based on several public lectures presented at the College de France from 1977 to 1981 (cf. Ewald, Fontana \& Senellart [eds. 2004, eds. 2012]; cf. Karskens 2019:577), which Foucault
himself did not finish and signed off at the publisher. Furthermore, even days before his death, Foucault explicitly prohibited any posthumous publication of his unfinished manuscripts, unpublished lectures, and related personal material. Foucault's insistence on 'no posthumous publications' was respected for close to 30 years until, in 2013 these manuscripts and related material (comprising around 100 boxes and 40000 pages of manuscript; cf. Chevallier 2021:1; cf. Massot, Sforzini \& Ventresque 2018:2) were transferred from a bank vault to the existing Foucault archives in Paris. While acknowledging this problem surrounding and the discomfort of some Foucault scholars regarding the eventual publication of the unfinished manuscript Les aveux de la chair regarding the eventual publication of the unfinished manuscript Les aveux de la chair (cf. Sforzini 2021:1), the greater consensus in the international Foucault scholarship after 3 years of intensive debate and after reconsidering Gros' eloquent explanations in the forewords of the original French text and the English translation (cf. Gros 2021:viixiii), seems to be that the edited text can now for all practical purposes be accepted and used as the 'fourth' volume in the series (cf. Clements 2021a:1-40, 2021b:1; c Chevallier 2021:1; hereafter thus referred to without quotation marks). The editing and publication of a fifth and a sixth volume are already considered to be feasible (probably to be based on the substantially drafted manuscripts La chair et le corps and La croisade des enfants, currently at the [thus since 2013] expanded Foucault archives [NAF 28730] at the Bibliothèque Nationale; cf. Sforzini 2021:1; Raffnsøe 2018:419-421; although Gros [2021:vii] seems to have doubts about it ['None of these works will see the light of day' - referring in particular to three other manuscripts as well, La femme, la mère et I'hystérique, Population et races and Les pervers]). References to Les aveux de la chair in this article will thus be made to Foucault as its author, accepting it as the fourth volume in the series Histoire de la sexualité.

3. Note that the references to the three earlier volumes of Histoire de la sexualité in this article refer to the publication dates of the original French texts (Foucault 1976, 1984a, 1984b), but refer to the page numbers in the English translations by Robert Hurley, as listed in the bibliography, for the sake of English-orientated accessibility. References to the fourth volume are, however, to the Gallimard edition in French References to the fourth volume are, however, to the Gallimard edition in French only: Hurley (transl. 2021) presented an English translation of Les aveux de la chair in early 2021, again at Pantheon in New York, which published two of his translations
of the earlier volumes (cf. Foucault 1976 [1978], 1984b [1986]) - yet until possible translation issues in Hurley's most recent (and indeed deeply appreciated) offering have been addressed in the scholarship, it seems prudent to page-refer to the French text only for the time being. A first Dutch translation of the first three volumes was presented by Klinkenberg et al. (transl. 1984-1985) in three separate sections, followed by a magnificent translation by Jeanne Holierhoek (transl. 2017) in a single volume, while Holierhoek (transl. 2020) presented the first (and again superb) translation of Les aveux de la chair in Dutch already in January 2020.

4. For concise, accessible introductions to Les aveux de la chair, see Elden (2018:293-311) and Leezenberg (2018a:1-5, cf 2018b:6-7). For more extensive and specialised analyses, see Clements (2021a:1-40), Karskens (2019:559-581) Raffnsøe (2018:393-421) and especially Westerink's (2019a) insightful book in whole. For an overview of the extensive dissemination of Les aveux de la chair within weeks of its
Holierhoek's [transl. 2020] Dutch and 416 in Hurley's [transl. 2021] English translation), in three parts, with four untitled excursions. Only the third and last chapter of part III (thus the last chapter of the work itself) deals with the 'flesh' (chair) as such and indicates how specifically Augustine (354-430) transposed the orgasmic experience with another subject to the sexual desire of the lustful subject itself (where, on John Cassian's [ca.360-435] trail, the relational, intersubjective sexual event is radically narrowed down to the self-investigating and eventually self-confessing subject; cf. Westerink 2021; cf. Beukes 2021a:1-3; 2021b:1-4).

Part I (la formation dune expérience nouvelle, 'the formation of a new experience') consists of four chapters. The first chapter explores regulations and routines within early Christian monastery communities and families concerning ta aphrodisia, ( $\tau$ á A $\varphi \rho o \delta i ́ \sigma ı)$ or erga Aphrodites, as the Greeks (and Foucault, by preference) referred to it, that is 'all things sexual' (indicated within an overtly Augustinian context as marital issues in general, including sexual activity with the pertinent intention of procreation and the denial of sexual pleasure precisely within matrimony). The following three chapters in part I deal with concomitant forms of confession in early Christianity (confession of faith [in 'laborious baptism'], confession of guilt ['the second penance'] and general confession ['the art of arts', as the institutional domain for the 'confessions of the flesh']). Part II, in which Methodius features prominently, engages the 'virginal life' (être vierge, 'being a virgin'), which includes the relation between virginity and continence, 'on the arts of virginity' and the relation between virginity and self-knowledge. These three chapters explore the monasterial art of living together (as 'virgins'), the necessity of constant self-investigation and the acquisition of self-knowledge through celibacy as a positive illustration of chastity. Part III focuses on the 'married life' (être marié, 'being married') concerning the regulations for and the responsible routinisation of sex within matrimony, regarding 'the duty of spouses' (le devoir des époux,) 'the good and the goods of marriage' (le bien et les biens du mariage) and 'the libidinisation of sex' (la libidinisation du sexe). Augustine predictably features prominently in this part, as made clear already by these three titles. ${ }^{5}$ The four excursions deal with the following: (1) the relatively stable corpus of instructions for confession in Greek and Roman literature; (2) the virtually unchanged incorporation of that corpus into first- and

\section{(footnote 4 continues..)}

publication in the Netherlands in particular, see Beukes (2020a:2-7). Two outstanding monographies preceding the publication of Les aveux de la chair but explicitly dealing with the later Foucault, are Stuart Elden's (2016) Foucault's Last Decade and Michiel Karskens' (2012) Michel Foucault, while Niki Clements' (2021c:forthcoming) Foucault the Confessor, given her outstanding recent analysis of Les aveux de la chair, positioned within Foucault's massive oeuvre (cf. Clements 2021a:1-40), is awaited with anticipation. For excellent initial readings of Foucault's interpretation of early Christian sexual ethics, both with reference to Histoire de la sexualité 2 (L'usage des plaisirs, Foucault 1984a) and Histoire de la sexualité 3 (Le souci de soi, Foucault 1984b), see Cameron (1986:266-271), her colleague, the eminent specialist of patristic history, Elizabeth A. Clark (1988:619-641), and indeed Vandermeersch's (1985c:250-277) profoundly intuitive 'Michel Foucault: een onverwachte hermeneutiek van het christendom?'. Interestingly, Cameron (1986:222) refers already on the first page of her early analysis to 'one Les aveux de la chair, which is not yet published, but it is clear in which direction it is going'. We now know precisely which direction it has gone - as both Cameron and Vandermeersch predicted, straight to the heart of early Christianity.

5.It is noteworthy that the one text of Augustine that deals explicitly with confessions - Confessiones - does not feature in Les aveux de la chair. Confessiones does feature a single time in L'usage des plaisirs (Foucault 1984a:40) 
second-century patristics; (3) the alteration of that virtually unchanged corpus in the redefinition of the relation between subjectivity and truth in third- and fourth-century patristics, especially concerning a reinterpretation of sexual pleasure and the economies it gives birth to; and (4) that this redefinition of the relation between subjectivity and truth does not come down to a prohibition as such, but rather to an analysis of a framework wherein sexual desire was allowed and how subjects in early Christianity had to conform to that framework.

In his Collège de France Leçons 1974-19756 (delivered on 19 February 1975, thus shortly before the publication of $\mathrm{La}$ volonté de savoir in 1976; cf. Karskens 2019:577 [fn.70]), Foucault explored the early (Pauline, but not explicitly) and later Christian distinctions between the body (corps) and bodily pleasures (plaisirs) on the one hand, and the (sinful) 'flesh' (chair) and its pleasures or 'lusts' (désirs) on the other, but restricted himself to 17th-century texts of penance. Foucault argues on the premise that $L a$ volonté de savoir departs from a year later (and Les aveux de la chair in 2018 be concluded with the exposition on Augustine), that the subject's confession is not directed towards the verbalisation of a sinful lust in sexual encounters with other subjects, but on the progressive revelation of the subject's own sexual desires and intimate thoughts, always and still in service of a 'will to knowledge'. La volonté de savoir puts body and flesh, in this articulated sense, in opposition. This disparity is extended in the distinction between ars erotica and scientia sexualis as 'cultural', namely between bygone Western cultures (Rome included) and the modern (Western) postChristian culture (cf. Beukes 2019:1-2; 2020c:1-3). This last opposition is being engaged systematically in La volonté de savoir, with the proposal (Foucault 1976:208) that a series of consecutive works would launch a counterattack on the modern invention of sexuality, not finding support on the flesh and desires (chair and désirs), but on the body and bodily pleasures (corps and plaisirs). From the sequential development of L'usage des plaisirs to Le souci de soi to Les aveux de la chair it becomes clear that there was, in Foucault's view, a noticeable shift (yet also a discursive continuity) from the aestheticisation of the desires in Hellenism, to the subtle ethitisation of it in Roman contexts, to the attempted control over it by the church fathers. In the latter context, Methodius played a significant role in his accentuation of chastity (áyveía) and virginity $(\pi \alpha \rho \theta \varepsilon v i \alpha)$, which Foucault explored in Part II of Les aveux de la chair.

\section{Patrick Vandermeersch's oeuvre, 1974-2021, and its relation to Foucault and Methodius}

Patrick (P.M.G.P.) Vandermeersch (born in Bruges, Belgium, 1946) is professor emeritus of the Faculty of Theology and

\footnotetext{
6. For an accessible and recently reviewed table of all Foucault's College de France Lecons, dating their original presentation with precision, tracing their initia publication in French and eventual translations in English, as well as a meticulous table of dynamic data visualisations, indicating Foucault's citations from patristic table of dynamic data visualisations, indicating Foucault's citations from patristic
texts, see Clements (2021a:6-7, 2021b:1; also at http://www.nikiclements.com/
} foucault/, viewed on 30 May 2021).
Religious Studies at the University (Rijksuniversiteit) of Groningen in the Netherlands. He studied theology and philosophy and was trained as a psychoanalyst at the Belgium School for Psychoanalysis. After completing his doctoral thesis on the concept of the unconsciousness in Freud and Jung in 1974, he was appointed professor of ethics at the KU Leuven (Catholic University of Louvain, Belgium). Inspired by Foucault in particular, his research from 1978 to 1992 focused on the ethics of psychiatry and its relation to the history of sexuality. In 1992 he became a full professor of psychology of religion at the above-mentioned faculty in Groningen. His subsequent research shifted to the multiplicity of psychological dimensions in the psychological act called 'believing' and the various ways religion and ethics can interact. Yet Vandermeersch's main interest and the bulk of his research from 1992 up to his retirement in 2008 and thereafter engaged the narcissistic, aggressive and sadomasochistic aspects of religious life, with its clear Foucaultian undertones regarding 'power' and the 'will'. Subsequent extensive investigations into the religious ritual of flagellation, in particular, became an essential feature of his work. ${ }^{7}$

Vandermeersch's most important and consequential books include La chair de la Passion - Une histoire de foi: la flagellation (Vandermeersch 2002), Unresolved Questions in the Freud/Jung Debate-On psychosis, sexual identity and religion (Vandermeersch 1991a; see Vandermeersch 1992d for the text in Dutch), Ethiek tussen wetenschap en ideologie (Vandermeersch 1987), ${ }^{8}$ Passie en Beschouwing - De christelijke invloed op het westerse mensbeeld (in which he engages Methodius' thought and legacy extensively, Vandermeersch 1988), Carne de la Pasión (Vandermeersch 2004, the Spanish translation of La chair de la Passion, cf. Vandermeersch 2002), and Laïcite, théologie et sainte ignorance - Histoire d'une mésente (Vandermeersch 2020). ${ }^{9}$ Apart from these key works, Vandermeersch's

7.On 09 April 2021, permission was requested for extensive referencing to and paraphrasing of (unavoid (t) contents from Dutch to English) on Foucault's reading of Methodius, which Vandermeersch granted on the same date. Permission was, on 18 May 2021, subsequently requested to contextualise this unreviewed paper in Vandermeersch's broader oeuvre, with reference to the publication listings provided at https://patrickvandermeersch.org/ to systematise these book-, chapter- and article publications into a concise and coherent overview of his oeuvre, as reflected in the main text (part 2) and the bibliography of this article. Professor Patrick Vandermeersch permitted this second request on the same date and is hereby extended my sincere gratitude for this permission, as well as his willingness to assess the factual correctness of the relevant sections in the pre-review draft of this article. I nevertheless accept full responsibility for any shortcomings in the published version of the review and post-review manuscripts of this article.

8.Vandermeersch wrote this book after he was 'compelled to withdraw from the Theological Faculty of Leuven in the late 1980s as' his teaching was said 'not to folow tha Fuly the follow the classical classical order. Psychologically speaking, "norms come first and only subsequently the question arises what facts can challenge those norms'. Vandermeersch subsequently draws important conclusions for 'ethics as a science and for teaching on ethics'. He elaborated on this important topic in a later book chapter, 'Hooglerarenmoraal: Die wijnschenker en de pentiumprofessor' (cf. Vandermeersch 1996a:217-234). See https://research.rug.nl/en/publications/ethiek-tussen-wetenschap-en-ideologie viewed on 28 May 2021.

9.Vandermeersch's other books are (in publication order): Het gekke verlangen Psychoterapie en ethiek (Vandermeersch 1978), Psychiatrie, godsdienst en gezag-De ontstaansgeschiedenis van de psychiatrie in België als paradigma (Vandermeersch ontstaansgeschiedenis van de psychiatrie in Belgie als paradigma (Vandermeersch 1984), Flarden - Geestelijke verzorging in het verpleeghuis (Vandermeersch 1999a), God, Biblical Stories and Psychoanalytic Understanding (co-authored with Raine Kessler; cf. Kessler \& Vandermeersch 2001), Godsdienstpsychologie in cultuurhistorisch perspectief (co-authored with Herman Westerink [cf. Vandermeersch \& Westerin 2007]; for a brief overview of the objectives and scope of this work, see Westerink 2019b:34-38), and Scepticisme als vorm van geloof - Beschouwingen van een godsdienstpsycholoog (Vandermeersch 2016). Vandermeersch is thus the sole author
of 10 and the co-author of two books. 
extensive range of accredited articles and book chapters draws attention to the scope of his erudition, particularly with regard to the history of sexuality and its relation to psychiatry, religion and theology, in which several themes explicitly relating to topics in Foucault's history of sexuality are addressed. ${ }^{10}$

In December 2017, merely two months before the publication of Les aveux de la chair, Vandermeersch (2017a:1-21) presented a colloquium lecture on 'Foucault and Christianity'. Again, his intuitions regarding the direction Foucault took in Les aveux de la chair - straight to the souls (and bodies) of the desert- and church fathers - were proven to be correct. The question is what precisely (in)formed these intuitions regarding Foucault's relation to Christianity (as already back in 1985; cf. Vandermeersch 1985c:250-277). This has clearly to be found in the notions of (a problematic and self-challenging) virginity and (to a lesser extent) chastity, as presented by Methodius. For Vandermeersch, Methodius is as crucial a figure in Les aveux de la chair as Cassian and Augustine.

The arduous efforts of the academic society Foucault Cirkel Nederland/België bear witness to its thorough engagement of Les aveux de la chair within weeks of its release in February 2018 (cf. Beukes 2020a:2-7), contextualising La volonté de savoir en L'usage des plaisirs in a coherent framework towards its development to Les aveux de la chair (or backward from Les aveux de la chair to these second and third volumes, depending on how one reads the chronological interplay between the

10.In publication order: On the relation between introversion and autoeroticism (Vandermeersch 1975:314-315); On the relation between psychoanalysis and ethics (Vandermeersch 1976:162-182); On critical distinctions between religion and the origins of psychiatry, and between theology and the sciences of the psyche (Vandermeersch 1979:329-351); On the role of confession and desire in religion (Vandermeersch 1980:252-259); On the history of the concept narcissism (Vandermeersch 1982a:32-58); On the attachment of religion to authority (Vandermeersch 1982b:311-331): On the development of the 18th century campaign against masturbation and onanism into the mid-20th century (Vandermeersch 1985a:173-193); On the relation between medicine and religion in the origins of psychiatry in Belgium (Vandermeersch 1985b:1-10); An - in retrospect a strikingly perceptive -investigation into Foucault's 'unexpected hermeneutics of Christianity', more than three decades before the eventual publication of Les aveux de la chair (Vandermeersch 1985c:250-277); On scepticism as a 'form of faith' (Vandermeersch 1989:102-108); An investigation into the intimate relation between sexuality and culture (a 'cultural sexuality or a 'sexual culture?'; Vandermeersch 1990a:43-58); On phallocracy and psychoanalysis (Vandermeersch 1990b:39-43); On 'the whole truth of the past' (whether psychoanalysts are 'masters of the discovery of truth', rather than 'creators of truth'; Vandermeersch 1990c:274-276); On the relation and differences between psychotherapeutic and religious 'rituals' (Vandermeersch 1991b:24-33); On the victory of psychiatry over 'demonology' and the origins of this particular 19th-century myth (Vandermeersch 1991c:351-363); An analysis of modern Dutch philosopher Gerardus Heymans' (1857-1930) 'panpsychist hope' (Vandermeersch 1992a:437-440); Questioning moralisation under the cover of 'nature' (Vandermeersch 1992b:45-62); On pastoral relationships and sex (Vandermeersch 1992c:53-62); On 'perversion' as the 'natural complement of neurosis and psychosis' in the psychology of religion (Vandermeersch 1993:37-52); On self-inflicted pain (the 'justified use of flagellantism') and its appeal in religious contexts (Vandermeersch 1995:215-242); On the 'world view' in pastoral healthcare (Vandermeersch 1996b:1-24); On 'passions and virtues' (Vandermeersch 1996c:99-119); On Foucault's significance for psychiatry (Vandermeersch 1997:141-146); A psychoanalytic view on the biblical stories of the flood, thus on the fundamentals of the biblical account of $\sin$ (Vandermeersch 1998a:50-70; cf. Vandermeersch 1998b:21-53); On the analysis of the 'endless' as impetus for the psychoanalytic study of the science of religion (Vandermeersch 1998c:31-56); On the relation between revolt and knowledge (Vandermeersch 1999b:345-534); On 'revolting passion' (Vandermeersch 1999c:250-253; cf Sforzini [2021:1] on 'rebellious flesh'); On 'lust in Christianity' (in which both Methodius and Foucault feature prominently; Vandermeersch 2000:1-13); On self-flagellation in the early modern era (Vandermeersch 2008:261-273); and lastly, on 'juridic fiction in the service of true love' (Vandermeersch 2011:73-83). four volumes; cf. Beukes 2022:1]). ${ }^{11,12}$ Vandermeersch's (2021:1-20) concluding analysis of Foucault's reading of Methodius was presented from this societal context ${ }^{13}$ : as indicated supra, already in 1985 and 2000, thus well before the editing of the unfinished manuscript Les aveux de la chair commenced, and then finally in 2017, just two months preceding its publication, Vandermeersch (1985c:250-277, 2000:1-13, 2017a:1-21) presented preliminary analyses of Foucault's engagement with early Christianity. These three surveys form the backbone of Vandermeersch's latest reading: without strictly juxtaposing the four expositions, spanning over 36 years, his latest analysis (thus Vandermeersch's 2021:1-20) differs on no crucial point from the three earlier and, by definition, intuitive readings. In other words, Vandermeersch's analyses of Foucault's interpretation of Methodius' importance for his history of sexuality do not differ significantly from the decades before, vis-à-vis, the three years after the publication of Les aveux de la chair. Vandermeersch's analyses before and after 2018 are overall consistent, and the latest could thus be presented as his synthesised analysis of Foucault's interpretation of Methodius.

Methodius of Olympus was an Eastern church father of which very little is known biographically (Bracht 2017b:1), apart from the fact that he opposed Origen of Alexandria's

11.The textual development and publication history of the four current volumes in the series are intricate. Each of these texts' origins, objectives, and place within Foucault's larger oeuvre should be acknowledged to appreciate the current series Foucault's larger oeuvre should be acknowledged to appreciate the current series
as a coherent body of knowledge. However, when taken into account that the now as a coherent body of knowledge. However, when taken into account that the now
published "fourth" volume in the series should thematically and in terms of the published "fourth" volume in the series should thematically and in terms of the
time of its completion around 1980 rather be regarded as the current "second" time of its completion around 1980 rather be regarded as the current "second"
volume, while the published "second" (L'usage des plaisirs) and "third" (Le souci de volume, while the published "second" (L'usage des plaisirs) and "third" (Le souci de
soi) volumes which were only finalised and published in 1984, instead be considered the "third" and "fourth" volumes of the existing series, Foucault's "backward" development of the series (departing from early modernity and working its way back to antiquity) becomes more clear'. As mentioned in footnote 2 , if a '\#' fifth' (thus probably La chair et le corps) and 'sixth' (thus possibly La croisade des enfants) volume be added from the Foucault-archives (NAF 28730) to the current series of four volumes, these two texts would, in turn, have to be placed befóre Les aveux de la chair. The numbering of the 'second' and 'third' volumes in the series will, in this sense, always lead to confusion. Perhaps the most straightforward solution would be to primarily account for the 'retro-development' in the series rather than using the published numbers of the separate volumes. in the series rather than using the published numbers of the separate volumes. What will not change is La volonte de savoir will always be the first, L'usage des
plaisirs always the last and Le souci de soi the penultimate volume' (Beukes 2022:1 plaisirs always the last and Le souci de soi the pe
[quoted from the extended abstract in English]).

12.The latest contributions from the society include, inter alia: Steven Dorrestijn (2021, on technology as 'seductress', and the relation of subjectification and power in a technological culture; cf. Dorrestijn 2019); Marli Huijer (2021, on the differences and overlaps of confession in early Christianity and early modernity); Machiel Karskens (2021, on the 'religious codification' of spirituality with reference to martyrdom and self-sacfrice; cf. Karskens [2019:559-581], his critical and deeply erudite analysis of Les aveux de la chair); Marc De Kesel (2021, 'from lust to desire and back'); Michiel Leezenberg (2021, in a forward bound, anticipating reading of Foucault's significance for intuitions about the relation of sex, spirituality and governmentality in the later Middle Ages); Danny Praet (2021, on Foucault technologies of the Self and the ascesis of the desert fathers; cf. Praet [2020:213236] for a solid introduction to Foucault's reading of Augustine. cf Behr 1993:1-21] 236] for a solid introduction to Foucault's reading of Augustine; cf. Behr 1993:1-21 and Herman Westerink (2021, on Cassian, Augustine and the problem of the libido). Although not bearing on Les aveux de la chair as such, see from Foucault Cirkel Nederland/België also Treiber (2019) on the 'return of the early Foucault'
and the 'possible future publications of his 1960's lectures' (cf. Leezenberg [2019] and the 'possible future publications of his 1960's lectures' (cf. Leezenberg [2019],
for Foucault's 1960's lectures on sexuality [Deux cours inédits de Michel Foucault for Foucault's 1960's lectures on sexuality [Deux cours inédits de Michel Foucault
sur la sexualité], also published in 2018, and as Foucault's other lectures, by Seuil) and, in the same vein, Van Rooden (2019) on the publication of Folie, langage, littérature, published in 2019 by Vrin under editorship of Henri-Paul Fruchaud Daniele Lorenzini and Judith Revel.

13. In addition to the ongoing analysis and dissemination of Les aveux de la chair by scholarly societies such as Foucault Cirkel Nederland/België, contributions by several frontline Foucault scholars at a recent international conference, Foucault's Confessions, organised by the Department of Religion at Rice University (Houston, Texas), hosted by James D. Faubion and Niki K. Clements and attended by the author (04 May-03 June 2021), should be accounted for (cf. Bernauer 2021; Brown 2018:35-36, 2021; Chevallier 2021; Clark 2021; Clements 2021b; Huffer 2021; 2018:35-36, 2021; Chevallier 2021; Clark 2021; Clements 2021b; Huffer 2021;
Jordan 2021; Lorenzini 2021; Sforzini 2021). See https://foucaultsconfessions.org/ Jordan 2021; Lorenzini 2021; Sforzini 2021). See https://foucaultsconfessions.org/ (2020:114-151) recent and deeply informative evaluation of Foucault's reading of (2020:114-151) recent and deeply informative evaluation of Foucault's reading of
John Chrysostom's marital ethics in Les aveux de la chair should be in this reception context also be acknowledged for its discursive grace and scholarly erudition. 
(ca.184-ca.253) interpretation of the resurrection - whereas Origen allegorically held that a 'spiritual body' would be resurrected, Methodius claimed it would be the 'earthly body' (Bril 2006:301). The obvious intention of Methodius' Symposium, written in the last half of the 3rd century (the manuscript is fully extant in Greek) ${ }^{14}$ was to creatively refashion Plato's similarly named work: whereas Plato's Symposium engaged the nature and (for him, predominantly male homoerotic) foundations of eros, presenting the Athenian philosopher's theory of ideas in its last section, Methodius focused on the patristic virtues of chastity (áyveia) and particularly virginity $(\pi \alpha \rho \theta \varepsilon v i ́ \alpha)$, the latter presented to be the early Christian equivalent of eros, with its exponents proclaiming to be 'removed from earthly concerns' (Bril 2006:280). In Methodius' praise of virginity, he places a host and nine virgins in a symposium, each speaking in turn in the fashion of Plato's original characters, ${ }^{15}$ to which we will return shortly.

Vandermeersch (2021:1) indicates that his lectures on ethics in the 1970s engaged the history of sexual morality, with specific reference to the relation between sexuality and guilt as its point of entry, thereby addressing whether this relation pointed towards an inimitably Christian phenomenon. Although this work was scarcely noticed in Englishorientated contexts, since it was only translated in French and several other European languages but not in English, Belgian historian Jos van Ussel's (1968) De geschiedenis van het sexuele probleem took central stage in sexology in DutchBelgian and other European contexts in the 1970s - likewise, albeit very critical of it, in Vandermeersch's early work. Although not referring to him by name, Foucault (in eds. Ewald et al. 1999:39) also took note of Van Ussel's position, which primarily entailed that the relegation of sexual pleasure in the 18th and 19th centuries could be traced to industrialisation and bourgeosifying propensities during this period - and had no religious basis at all. During the period, the emphasis on production and efficiency was simply shifted onto sexuality - hence (even) the prohibition of masturbation, a leitmotif in Van Ussel's work, because, in a rephrase of the Medieval notion of onanism, it is a form of 'counter-productive excess' (cf. Vandermeersch 1985a:173-193). However, once capitalism was dismantled, a

14. Methodius is considered a central figure of interest in contemporary third-century Patristic research' (cf. Bracht 2017b:1). His other texts survived in Slavic versions and in fragments in Greek. These were edited and published in German by Nathanael Bonwetsch (1891). The Symposium itself as well as De resurrectione, discussed Bonwetsch (1891). The Symposium itself as well as De resurrectione, discussed
infra, was translated, edited, theologically embedded and annotated by, again, infra, was translated, edited, theologically embedded and annotated by, again,
Bonwetsch $(1903,1917)$. One of Foucault's $(2018: 170 \mathrm{ff}$.) own authorative sources, Bonwetsch (1903, 1917). One of Foucault's (2018:170ff.) own authorative sources, Jacques Farges' (1929) Les idée morales et religieuses de Méthode d'Olympe
(although misprinted as 'Parges' in Les aveux de la chair, cf. Foucault 2018:170), is (although misprinted as 'Parges' in Les aveux de la chair, cf. Foucault 2018:170), is
used by Vandermeersch (2021:13 [cf. fn.21]) in his reading of Methodius as well. A complete translation and annotation of Methodius' oeuvre were published in English by L.G. Patterson in (1997) after the first English translation of the Symposium by J.C. Quasten and J. Plumpe (1958). An editorial work in English by K. Bracht (ed. 2017a), succeeding her dissertation on Methodius in German almost two decades earlier (Bracht 1999), is in this context especially significant, as Vandermeersch (2021:14-15) critically engages her reception of Plato and Methodius (in Brach 2017c:38-62), as indicated infra. Another - for Vandermeersch (2021:16 [fn.3]) significant contribution from Bracht's (ed. 2017a) editorial work is A.B. Hughes' (2017:85-102) 'Agency, restraint and desire: Virginity and Christology in Methodius of Olympus', to which Vandermeersch refers with assent.

15.It is important to note that Methodius' indebtedness to Plato was not restricted to the Symposium - in Methodius' writings, references to inter alia De Republica, Timaeus, Phaedrus and Protagoras can be discerned (Bril 2006:280 [fn.9]). For Vandermeersch (2021:8-10), Methodius' engagement with Phaedrus is especially important, as shown infra. healthy and indeed mundane sexuality would naturally reappear. Justifiably - as even a cursory overview of patristic and early Medieval texts would point directly to the opposite; that sexuality was indeed profoundly engaged in early Christianity - Vandermeersch took up issue with Van Ussel.

Although Foucault agreed with Van Ussel that sex was redeveloped and sexuality thoroughly 'invented' in the Victorian period, he countered Van Ussel's version of the repressive hypothesis (Foucault 1976:1-36), immensely popular in Marxist circles in the 1960s, which claimed that Victorian society was characterised by the suppression of sex and all urges sexual, giving rise to diverse neuroses which would only be liberated by the cultural revolution of the 1960s, steered by psychoanalysts such as Wilhelm Reich (and indeed historians like Van Ussel). Famously, Foucault (cf. 1976:15-16) argued that this was a pseudo-liberation and merely a new form of power exertion, wherein subjects were again coerced to confess the truth about themselves as sexualised Selves, referring to the image of the hysterical woman (l'hystérique), the construction of the sexuality of children (L'enfant masturbateur), the Malthusian couple, the deviant or pervert (le déviant sexuel) and so forth (Foucault 1976:17-50). Vandermeersch, on the other hand, continued his historical relativisation of Christian ethics and inevitably, like Foucault somewhat later, ended up in patrology: of all the patristic texts, he found Methodius' Symposium most striking. However, in retrospect, Vandermeersch (2021:2) considers that both he and Foucault, in their singular perspectives on Methodius's views on sex and virginity - he from the notion of the relation between sex and guilt, Foucault from sex and self-examination - missed something essential in the church father's principal text. This has to do with Methodius' unique views on virginity itself.

\section{Methodius' Symposium and Plato's Phaedrus: Precisely which desires are to be negated?}

Just as Plato's Symposium, Methodius' work is essentially about encomium or praise: whereas Plato praises (male homoerotic) love, Methodius, however, praises virginity. The crucial element in Methodius' unique homage to virginity is that it has a rather dusky side, namely as a way to replace martyrdom or self-sacrifice. At the time of the Symposium's writing, the torment of Christians was past its peak, as embodied in the vicious Decian persecution of $250 \mathrm{CE}$ : the parameters for martyrdom, the highest of contemporaneous virtues, had now been set conclusively, and one could not equal what had been sacrificed under the short reign of Traianus Decius (ca.201-251, Emperor 249-251). Yet one could sacrifice something as precious as - indeed the prerequisite for - life itself: the realisation of one's sexuality. By being a virgin, one took up cause with a state of misery worse than martyrdom, if only because one's sacrifice is indefinitely extended: not the end of a noble Christian life is further at stake - but the full scope of a complete and miserable life without the realisation of one's sexuality. The 
martyrs suffered for hours; the virgins forever. When the martyrs' suffering is condensed into a single event of sacrifice, the virgins' sacrifices are virtually endless.

However, the fundamental consideration for Methodius is that the desires should be allowed to flare up and run free only then to be countered in chastity. The true virgin is one who has experienced the full intensity of sexual desire yet was able to 'say no' to it. In other words, in what could perhaps be described as a 'Methodian form of psycho-sexual flagellation', ${ }^{16}$ the virgin must allow herself or himself to become sexually fully aroused - and only then 'say no' (thus 'first came the Pleasure ... and then came all the Pain'). Therefore, authentic chastity and genuine virginity are established in the knowledge of precisely which desires are to be defied. The standardised reception of Methodius's Symposium holds that the work is an ideal-typical example of the influence of Stoicism on early Christianity but Vandermeersch (2021:3), against this indeed archaic reception, disagrees. When the Stoics held that the passions, including sexual desire, should be inhibited and suppressed to the point of disinterest, Methodius claims precisely the opposite. Already three decades ago, in his Passie en Beschouwing (Vandermeersch 1988), Vandermeersch directed the attention to Methodius' profoundly anti-Stoic approach to sexual desire. Again, virgins should allow themselves to fully experience its passion, with all the risks and dangers involved in that experience, so that they can designate the desires, with precision.

The context of Methodius' Symposium is subsequently one of luxury, fragrance, food, wine and intimate thoughts - worlds apart from the asceticism of the monastic contexts that would only start flourishing in the 4 th century. Ten virgins Euboulion (a secret sobriquet for Methodius himself), Gregorian, Arete, Marcella, Theophila, Thaleia, Theopatra, Thallousa, Agathe, Pricilla, Thekla, Tusiane and Domnina engage in dialogue at a luscious banquet about the virtues of chastity and virginity, claiming from different angles that virginity is the most beautiful and highest of all virtues. ${ }^{17}$ Yet this virtue comes with a price - the dangers and risks of seduction. At the very end of the text (sections 301-302), the value of this life-long confrontation with the actual experience of being sexually aroused and therefore possible seduction and still 'saying no' - is articulated by Euboulion in a final dialogue with Gregorian:

After all that has been said, it seems that the soul who had experienced the desire and was able to master it, is better than the soul who had experienced no desire and only because of thát was able to master it. ${ }^{18}$

16.My description, not Vandermeersch's

17.The contents of the extensive dialogues in Methodius' Symposium are not addressed here, as they can be readily accessed elsewhere. Vandermeersch (2021:4-7) used the Sources Chrétiennes (No 95) edition (Musurillo \& Debidour [intr., transl. \& comm.] 1963), while I used the dated but trustworthy edition of Philip Schaff (ed. 1885). I also consider Simon Goldhill's (1995:1-45) reading of Methodius' Symposium as of particular significance.

18.My dynamic translation. Schaff's (ed. 1885:599) somewhat old-worldly, syntactic translation reads: 'Therefore the soul which is concupiscent, and exercises selfcontrol, as appears from what has been said, is better than that which is not concupiscent, and exercises self-control'.
Methodius' emphasis on chastity is, again, not to be confused with a Stoic indifference towards sexuality. On the contrary, the virgin should allow the desires to flare up as intensely as possible; only then to 'say no' to it.

The crucial question is whether these virgins merely countered the sexual attraction of a man or a woman (cf. Beukes 2020c:3-4) who had aroused them. Because these virgins were by no means monastical figures and deliberately took pleasure in all the selfindulgent offerings of their banquet, they committed to the possibility of being seduced - and only by overcoming that possibility, they acquired holiness: 'saying no', again, came at a high price. Vandermeersch (2021:8) reflects whether this possibility could be central to the Christian notion of guilt - not having surrendered to the seduction but always risking submitting to it. Is that what is genuinely horrible about sexand are we, alongside Methodius, already on the way to Augustine's attempt to the accountable routinisation of sex and the libidinisation of sex a century later, precisely within être marié? Two counter-questions can possibly answer this question: First, specifically, which (kind of) sexuality is at stake here? And secondly, if sex is that horrible, how could it offer the basis for the virgins' mystical union with Christ, for Methodius 'the ultimate virgin'? Methodius' indebtedness to Plato now becomes clear: notwithstanding the obvious correspondence between Methodius' Symposium and Plato's Symposium, and the thematic overlapping of an indulging banquet, there are several references to Plato's Phaedrus in Methodius' text, and the latter plays a far more vital role in Methodius' argument. Of course, both authors engaged the spiritualisation of sex precisely by resisting its forceful appeal, but Plato centred his attention predominantly on male homoeroticism, while it soon becomes clear that he was not willing to take that resistance as Methodius did, to extremes. Again, Methodius' insistence on precisely which desires are at stake applies.

Unerotic as Plato's narrative ${ }^{19}$ may initially seem, a key passage in Phaedrus (237a-240d; cf. Plato in Waterfield [intr. \& transl.] 2002:16-22) points to the text's relevance for Methodius: Phaedrus enthusiastically approaches Socrates, telling him about an insight he acquired from a potential new lover - namely that it is better to fall in love with someone who is not in love with you, than with one who is. The first will always soberly advise you for your own good, while the latter, blinded by passion, will not. Although initially concurring with Phaedrus, Socrates eventually vehemently disagrees. In pederastic ${ }^{20}$ fashion, he tells Phaedrus how he

19.Phaedrus' narrative structure is well-known: departing from humankind's urge to obtain the higher good, that domain where the Platonic ideas thrive unscathed, Plato describes humankind's journey to the heavens, following the gods. The gods undertake their celestial voyage with a team of two exquisite and equal horses. According to their character and predisposition, human souls attempt to follow According to their character and predisposition, human souls attempt to follow one of the gods: however, the souls have a set of two unequal horses, one of which, the dark horse of the lower passions, constantly drags them back, down to may eventually reach the heavens in a series of incarnational coercions.

20.For the sake of clarity, despite its moral ambiguity and modern criminal association, pederasty is to be distinguished from paedophilia (the sexual abuse of pede prepubescerto sexually educate postpubescent boys and girls by an older person of the same sex. A postpubescent boy's first sexual experience was accordingly with an older man and a postpubescent girl with an older woman: It is not illegitimate to employ podern sexual terms and concepts when interrogating the ancient record, but particular caution must be exercised in order not to import modern, Western sexual categories and ideologies into the interpretation of the ancient evidence (Bril 2006:279 [fn.2]; quoted in quote). 
seduced a boy, indifferent as the boy initially was to his attentions. The boy had to be educated about his own attractiveness and empowered to respond to love. The notion of 'beauty' plays a fundamental role herein: the boy, without realising it, by his beauty alone, seduced his lover and, as if the older lover is some 'mirror', finds his beauty reflected back to him. In this reciprocity of beauty and seduction a mundane sexuality is transcended, and a philosophicalsexual way of life can be established. Thus, the dynamic of this eroticism is established in a didactical relation where the older - the lover - attempts to bring the younger to an appreciation of the higher good (here, beauty), thereby forcing the dark horse forward and upward. However, the older must choose his lover wisely, one that conforms to the same god the older himself serves - Zeus for philosophical spirits, Ares for combatative spirits, Apollo for artistic spirits, and so forth. As kindred spirits, the older and younger do not necessarily pray or contemplate together but the younger's beauty overcomes both as a remembrance of the divine reality of the higher good. This overcoming is not only aesthetically but passionately since the (taking of the) beauty of the younger's body constitutes an essential part of it. Even though he does not fully understand his own response (yet), the younger at last no longer refuses the advances of the older (cf. Vandermeersch 2021:9).

Which desires are thus to be negated? Plato's is clearly a different account of the spiritualisation of the erotic than what Methodius offers. Eros, in Plato, is to be captivated by beauty as a higher good: one should not 'say no' to this seduction, without brusquely 'saying yes' to sex for the sake of sex as such. The connection between Plato and Methodius is that 'saying no' (or maintaining a position wherein it remains possible to still 'say no') to sexual gratification is of central concern. The difference between Plato and Methodius is that the virgins in the latter's case do not engage in a cultic embrace of the beauty of earthly bodies - we do not even know which bodies, male or female, would be able to provoke Methodius' virgins' risk of seduction. With Plato, the emphasis is essentially on the allure of beauty, while Methodius underscores the experience of 'saying no' - precisely in a state of arousal. Given this fundamental difference, the central question remains why Methodius resolutely referred to Plato with his text's title, this key passage in the Phaedrus and some of its leading images - as addressed infra.

\section{Vandermeersch's analysis (of Foucault's reading) of Methodius}

One of Foucault's (2018:152-154) core premises in Les aveux de la chair is clear and simple: the church fathers did not procure a new or a stricter sexual code but extended the Hellenistic and, more particularly, the Roman version of it - what the fathers added, thereby constituting a 'new experience of the flesh', was the practice of chastity, or to be more exact, of virginity. Departing from this basic premise, Foucault's historical overview of the fathers' relation to sex starts with Tertullian's (ca.155-ca.240) and Cyprian's (200-258) practical considerations of how it would be possible to 'be a virgin' (être vierge), yet while still living in the basic domestic structures of early Christian society since monasteries did not yet exist. The only option was that the virgin had to be overtly recognisable as such - one had to be virginal or ultra celibate in the open and therefore not to be sexually engaged. Foucault (2018:161-176) subsequently presents the first of several more extensive expositions on être vierge in the work, that is, on Methodius' views, annotating ${ }^{21}$ several passages from the Symposium. However, Foucault (thus, in his engagement of the 'virginal life' in part II of Les aveux de la chair) does not isolate the key passage supra in Phaedrus (237a-240d) in Methodius' Symposium. He briefly focuses on 'saying no' in Methodius' Symposium but does not engage its unique form of 'psycho-sexual flagellation' and its commitment to sexual arousal to precisely specify which desires were to be negated. Foucault (2018:202-205) thus reads Methodius merely as a primary early example of the virginity ideal in contexts of ascesis and rising monasticism. However, it was only a century later (that is, the fourth century) where it would indeed become possible to posit virginity as a distinct technology of the Self, where self-analysis, under the guidance of a confessor, became a central concern. Foucault (2018:177), nevertheless, justifiably or not, postulates a continuity between Methodius and this later development (cf. Vandermeersch 2021:12-13).

In addition, Foucault surprisingly does not engage Methodius' confrontation with Origen regarding the resurrection of the body - as said, Origen claimed it to be a 'spiritual(ised) body, while for Methodius it referred to a 'glorified earthly body': surprisingly, because this 'glorified earthly body' is for Methodius predictably still sexual, with the integrity of its (virginised) sexual desire, fully intact. This omission in Foucault's review of Methodius leads, according to Vandermeersch (2021:13), to two questions: (1) What precisely does 'sexuality' mean for Methodius in his persistent references to Plato's Symposium and Phaedrus with their perspicuous homoeroticism - because it seems that Methodius himself held no differentiated erotic viewpoint, whether homoerotic or heterosexual, in particular; and (2) why exactly did Methodius' place such a significant accent on virginity as suffering, the value of which is its replacement of (conventional) martyrdom?

Answering these questions, Vandermeersch (2021:14-16) critically engages the specialised reception of Katharina Bracht $^{22}$ (1999:180-199; cf. Bracht 2017b:1-17, 2017c:38-62). In her juxtaposition of the literary structures of Plato's

21.Although exponents of specialised contemporary Patrology and Studies in Late Antiquity are, of course, entitled to isolate reception problems in Foucault's engagement with the desert- and church fathers, it is problematic to read Foucault's interpretation of fathers such as Methodius, Chrysostom, Cassian and Augustine as if he had any intention to contribute to Patristic research and Studies in Late Antiquity (as disciplines of simultaneous historical inquiry and literary analysis; cf. Brown 2021:1:1:02:47-1:03:15) as such. Criticisms of the 'theological meagerness' of Les aveux de la chair (cf. Dorrestijn 2019:1-2) fall into the same category: instead, the discursive significance of Foucault's interpretations of the category: instead, the discursive sirnificance desert- and church fathers should be recognised, namely that he endeavoured to describe (indeed not as thorough as somea ideahistorical trajectory, concerning the governing of sexual desire from Hellenistic to
Roman to patristic contexts.

22.Katharina Bracht (1967-) is Professor of Church History at the Theologische Fakultät of the Friedrich-Schiller-Universität Jena. See https://www.theologie.unijena.de/katharina_bracht. Viewed on 07 June 2021. 
Symposium and Methodius' Symposium, Bracht focuses on literary correspondences between the two texts - but intentionally circumvents the homoerotic tendencies in the first and the sexual-challenging aspects of virginity in the second. Bracht's exegesis rather concentrates on the main difference between Plato and Methodius, being that the attainment of eternal life by the individual believer is the ultimate terminus for the latter, while for Plato, the individual soul, after having witnessed the eternal truth of the gods, would again descend from the heavens to educate lesser earthbound souls on the higher good. Emphasising this ascending-descending (what she [Bracht 1999:191-193] according to Vandermeersch [2021:14] questionably so - calls a 'dialectical') movement of the soul, with specific reference to the Platonic allegory of the cave in De Republica, Bracht (1999:188) reads ${ }^{23}$ Platonic sexuality as predominantly heterosexual, with specific reference to a passage in the Symposium (208a-b; cf.206b) $)^{24}$ in which Plato posits procreation as a means to attain immortality. Bracht, however, does not expand on Plato's clear prioritisation of 'spiritual' rather than 'physical' procreation (Symposium 208e-209a ${ }^{25}$ : indeed, after a short reference to those 'who are drawn more towards women' and procreate physically accordingly (cf. Symposium 208e), ${ }^{26}$ Plato insists that the ascension to the higher good starts 'through loving boys in the right way'. ${ }^{27}$ Following her 'dialectical' reading of the Platonic witnessing of the ultimate truth, Bracht (1999:203) insists that the spiritual purpose of the virgins in Methodius' Symposium should be recognised as a beholding, albeit, other than Plato, as one eternal and immortal, of 'this beauty as justice, sobriety and love itself, being truth, understanding, reason and peace' ${ }^{28}$ For Plato, this beholding is an 'immanent' one, in the sense that the soul carries the faculty of the (aspiration to the) higher good in itself, while, according to

23. Unsterblichkeit bedeutet nach Platon für den Menschen keineswegs die Unsterblichkeit des Individuums, sondern vielmehr den Erhalt seines "WieUnsterblichkelt des Individuuns, sondern vielmehr den Erhalt seines "WieBeschaffenis," dessen, was seine Person ausmacht. Dieses Fortbestehen wird dadurch garantiert, dass das Veraltete stets ein anderes Neues, das eben von gleicher Art is wie es selbst (oion auto en), zurücklasst (Symposium 208b). Das und findet sowohl im körperlichen als auch im seelischen Bereich statt (206b)' und findet sowohl

24.'In this way, everything mortal is preserved, not by remaining entirely the same forever, which is the mark of the divine, but by leaving behind another new thing of the same kind in the place of what is growing old and passing away [...] So do not be surprised that everything naturally values its offspring'; 'All human beings are pregnant [...] in body and in soul, and when we reach maturity it is natural that we desire to give birth [...] the intercourse of a man and a woman is a kind of givin birth. It is something divine, this process of pregnancy and procreation. It is an in \& Sheffield 2008 [208a-b, p.46; 206b, p.44]).

25.'But [there are] those whose pregnancy is of the soul - those who are pregnant in their souls even more than in their bodies, with the kind of offspring which it is their souls even more than in their bodies, with the kind of offspring which it is
fitting for the soul to conceive and bear. What offspring are these? Wisdom and the fitting for the soul to conceive and bear. What offspring are these? Wisdom and the
rest of virtue [...]' (Plato in eds. Howatson \& Sheffield 2008 [208e-209a, pp. 46-47).

26.'Those whose pregnancy is of the body [...] are drawn more towards women, and they express their love through the procreation of children, ensuring for themselves, they think, for all time to come, immortality and remembrance and happiness in this way' (Plato in eds. Howatson \& Sheffield 2008 [208e, p. 46).

27.'Now, whenever someone starts to ascend from the things of this world through loving boys in the right way, and begins to discern that beauty, he is almost in reach of the goal [ ] That is the life [ . ] which most of all a human being should live, in the of the goal [...] That is the life [...] which most of all a human being should live, in the contemplation of beauty itself [...] If ever you see that beauty, it will not seem to you to be comparable with gold or dress or those beautiful boys and young men who
drive you [...]' (Plato in eds. Howatson \& Sheffield 2008 [211c-d, pp. 49-50).

28.'Methodius bestimmt diese Schönheit genauer als die Gerechtigkeit, die Besonnenheit und die Liebe selbst, als Wahrheit, Einsicht, Vernunft und Frieden (Bracht 1999:203).
Bracht (1999:204-205), for Methodius, it is acquired by the grace of God alone. ${ }^{29}$ Bracht (2017c:38-62) more recently confirmed her 'dialectical' perspective on Methodius by interpreting (spiritual) procreation, which, according to her reading of Plato supra, is the purpose of eros, as the conception of repentant, new Christians through baptism. Again, Bracht refrains from references to homoeroticism altogether, as several other authors who, without a blink, transpose Plato's praise of eros to Methodius' ideal of virginity. ${ }^{30}$

In answering the two questions raised supra - what precisely does 'sexuality' mean for Methodius, since he held no differentiated erotic perspective, and why did Methodius' place such a considerable accent on virginity as suffering, being a substitute for martyrdom - Vandermeersch (2021:16-18), in subtle conjunction with Hughes (2017:85-102), argues that 'sexuality' for Methodius is directed to the transformation of sexual desire in his encomium of virginity, based on the incarnation of Christ: just as Christ was, according to the specific dogmatic articulation, fully and equally bodily and divine, the love for Christ should also reflect a love both bodily and nonbodily - however, not 'spiritually' since Methodius is convinced that the real, earthly body shall be resurrected. While there will be no procreation in heaven, the body will remain sexual(ised) with its sexual desire intact, albeit 'sublimated'. ${ }^{31}$ This is why Methodius found no reason to specify the meaning of 'sexuality' or the source of sexual desire, whether homoerotic or heterosexual: since the desire is to be transformed, its source is irrelevant. This transformation of desire points at once to the import of virginity - keeping intact the sexual integrity of the body to be resurrected. With the Freudian term 'sublimated' and its connection to the resurrection, we arrive at the heart and true originality of Vandermeersch's reading of Methodius and his analysis of Foucault's analysis in Part II of Les aveux de la chair.

As noted, Foucault did not engage Methodius' interpretation of the resurrection of the body. However, this oversight is understandable since very relatively few commentators outside of specialised patristics research have picked up on the relation between the ascension of the virgins to heaven and Methodius' conception of resurrection. The greater part of Methodius' work on the resurrection exists (still unedited) in Old Slavonic while it was edited and translated into German by G.N. Bonwetsch (1917) and recently also published in Italian (cf. Mejzner \& Zorzi [intr. \& transl.] 2010). In his text, Methodius launched a multifarious attack on Origen's claim that the resurrected (in Christ's) body to be a 'spiritual(ised)' one, including the notion that Adam and Eve's clothing of themselves after the Fall did not refer to their bodiliness, because they had possessed that already in paradise - rather,

29.Justifiably, Vandermeersch (2021:15) questions this interpretation: indeed, are we still in the company of Plato and Methodius here, or in (an eisegetical reading toward - my remark) the company of Luther?

30.See, for example, LaValle Norman (2017:30): 'There is a simple and clear substitution of Plato's encomia to eros and Methodius' encomia to hagneia'.

31.Cf. Hughes (2017:99): 'Methodius is working from an eternal contextualisation of the erotic that necessarily sublimates an embodied expression of sexuality between two humans in order to express an erotic relationship on a completely different level between divinity and humanity'. 
according to Methodius (in Mejzner \& Zorzi [intr. \& transl., infra also] 2010:II:223), the clothing signified their mortality. Methodius also quotes several medical theories about the relation of the body and the soul: will the faithful be resurrected with an old or a young body, with or without hair, with or without the blood possibly spilt at the time of death? This time aligned with the Stoics, Methodius in this context also describes the soul as a material entity.

However, Methodius' crucial rhetorical question is whether the glorified, resurrected body would be still a sexual one: he replies, remarkably, in the affirmative - but that it would be chaste bodies only. In a visionary excursion (II:223), Methodius muses over a great fire on Mount Olympus, with a chaste tree (agnus catus), so-called because of its symbolic association with chastity and under which both Plato's Phaedrus and Methodius' virgins conducted their symposia, engulfed in flames: even while burning, the chaste tree still radiated a vigorous viriditas. Towards the end of his text, Methodius (III:267) postulates that the glorified, resurrected human body would be characterised by a likewise 'green' chastity and now 'natural' restraint, which it did not hold before its glorification (cf. Vandermeersch 2021:17). Origen maintained a dualism where the external form of the body (eidos) is pertinently differentiated from the soul and that it would be this form to be imprinted on his notion of the resurrected 'spiritual body': Methodius (III:247-249), on the other hand, thinks about the resurrected body in profoundly concrete terms. Will we be resurrected with all vital organs intact and functional, will we still need teeth because we will not need to eat, will we need hands and feet, because we are not going anywhere, and what about our other organs, including our sexual ones? If we are stripped from all our organs, the glorified body may as well be geometrically depicted as one that is resurrected as a cubic, a cylinder, a polygon or a pyramid (III:15). However, Christ's resurrected body was bodily: even though Christ was the ultimate example of chastity and virginity, Christ's resurrected body could be witnessed and touched, it was indeed an exalted and glorified body - yet earthly, as the resurrected bodies of the virgins would be (III:12). Sexual desire is, therefore, not authentic to the body but has an external source, whispered to the post-fallen souls by the non-good agent to 'abuse their free will' - which is precisely why this Methodian ideal of virginity is so agonising (cf. Vandermeersch 2021:18).

\section{Conclusion: How, then, does Methodius fit into Foucault's history of sexuality?}

With all this in mind, Vandermeersch (2021:18-19) takes us back to the last section in Histoire de la sexualité 2 (L'usage des plaisirs, Foucault 1984a:227-246, titled 'True Love'), where Foucault expands extensively on the Athenian 'love of boys' (Knabenliebe): this widely accepted practice in classical Athens was regulated by a complex system of rules, of which Plato's nuanced depictions of it in Phaedrus are a good example. ${ }^{32}$ Foucault, however, pertinently indicated that Plato's understanding of homoeroticism did not conform to these rules: what differentiated Plato of the other Greek authors for Foucault was that he did not focus on the acceptability (or not) of and the possible transgressing elements in homoeroticism, but on its deeper and indeed transcendent meaning. ${ }^{33}$ In this sense, Foucault argues, Plato underpinned what was later in Christianity recognised as the mystical, transcendent dimension of love. Plato's readers should thus not fixate on the presentation of Aristophanes in the Symposium according to which the different forms of human sexual interaction are related to the division of the original hubristic male/male, male/female and female/female beings: the search for one's true and primordial soulmate is for Foucault specious and more important is that Plato penetrated the heart of human desire. Although just briefly, Foucault (1984a:249-254) in this very last section of L'usage des plaisirs indicates the culmination of his historiographical project: Knabenliebe boils down to the fascination with beauty (in the guise of a boy), bringing about a shared passion for truth. This passion demands discipline - indeed ascesis and the constant dearth of virginity - as it would manifest itself as central notions in early Christianity. However, before this passion could reach Christianity, it was mediated by later Roman medicine and philosophy, where women took the place of boys and became the focal point in the self-reflection on sexual desire - hence the patristic import of virginity, cumulating in Augustine's theoretical exposition on the Christian problematisation of sexual desire and the libidinisation of sex (cf. Beukes 2021a:1-3; 2021b:1-4). Subsequently, the problematisation of sex progressively focused on the Self, the own body and own desires, narrowing down towards modern scientia sexualis' interests in the

32.For an accessible overview of these rules regarding Knabenliebe in classical Athens, see Waterfield (2002:xiii-xvi): apart from being an upper-class phenomenon and Athenian men's general preference for both heterosexual and same-sex anal intercourse for fear of unwanted pregnancies, the 'love for boys' was deeply intercourse for fear of unwanted pregnancies, the 'ove for boys' was deeply
ritualised. While a postpubescent boy (around the age of 15) was 'in bloom', as the ritualised. While a postpubescent boy (around the age of 15) was in bloom', as the
Greeks called it, several older men, from their later twenties onward, would pursue Greeks called it, several older men, from their later twenties onward, would pursue
him. These older men were 'the ones feeling passion, while the boy would most him. These older men were the ones feeling passion, while the boy would most
likely feel little or nothing beyond sexual arousal [...] The boy was expected to be merely passive, to let the successful suitor have his way [...] This inequality is reflected in the relevant Greek terms: "lover" translates erastes, literally "a man feeling eros", while the boy is the eromenos, just the object of the lover's eros. What the boy got out of the affair - and that is why it was an upper-class phenomenon - was a form of patronage. In return for granting his sexual favours, he would expect the older man to act as an extra guardian in public life [...] Moreover, the older man was expected to cultivate the boy's mind - to be an intellectual companion. It was, in effect, a form of education [...] Such homoerotic relationships were widely tolerated but not universally approved (in Phaedrus, see 234b 231 and 255a). It was felt that there was something demeaning a beut it 234b, 231e and 255a). It was felt that there was something demeaning about it especially for the boy [...] (However,) [I] ust in any context was never approved of [... we can be sure that Plato himself (and probably the historical Socrates) Phaedrus itself, at 250e-251a and 253c-256e [...]' (Waterfield 2002:xiv-xv).

33. In conjunction with the previous footnote: if Plato disapproved of the sexual side of homoeroticism, why did he still use it as the background to the Symposium and Phaedrus, his two major works on love? Waterfield (2002:xvi) provides two plausible answers (while acknowledging that Plato's personal preferences in this regard are 'imponderable' and indeed not relevant). Firstly, 'Athenians rarely married for love: a wife was for bearing children, while slave-girls were used for extra sex. Love, then, was more likely to be met outside marriage - and it might be a younger man who aroused it. And this goes not just for love, but even for the shared interests that underpin love: the educational potential of a love affair, always one of the main things that interested Plato was unlikely to be fulfilled in always one of the main things that interested Plato was unlikely to be fulfilled in one's marriage [...]. Secondly, with women clearly regarded as sex-objects in Athenian culture, Plato 'felt that it was all too easy to get caught by the physica side of a heterosexual relationship [...] '(in a homoerotic relationship) there was at least the opportunity for the sexual energy to be channelled towards higher, spiritual or educational purposes'. As Goldhill (1995:ix; cf.162) sardonically quotes from a late Greek text: 'Male lions don't desire male lions, because lions don't do philosophy' (Ps.-Lucian, Erotes 36). 
sexuality of children, women, populations, races - in short, the relationship between sexual behaviour, normality, sanitation and health. With his attempt to draw the discursive circle towards La volonté de savoir, the question remains what the place of bodies and their desires in Foucault's circle is and how figures like Methodius fit into his history of sexuality (cf. Vandermeersch 2021:19).

Vandermeersch articulated Methodius' emphasis on 'saying no' with good reason - indeed, it could be argued that his praise of virginity was in itself an exercise on the challenges to and the limits of the will as such. In Methodius, it has been shown, we do not find a specification of sexual desire but rather an attempt to transform it. Precisely which desires are to be negated are only those the virgins themselves allowed to flare up, without referring them to a particular orientation. Methodius' contribution, springing from his own 'battle for chastity', could be limited to him being the first in a line of early Christian theologians who attempted to bring sexual desire under discursive control. This, as has been shown, was how Foucault basically read Methodius, with the addendum that Methodius was the key interpreter of the 'new experience of the flesh' or a new identity, namely that of a Christian virgin - and as such was clustered by Foucault in the company of the selfinvestigating monks of a century later. Vandermeersch's analysis points towards Methodius as a much more complex figure who articulated a much more robust framework: we do not encounter any form of self-analysis in Methodius, and the virgins' desires, at the most, refer to particular objects of arousal. Did Methodius postulate, as a consequence, a new form of narcissism, where a group of women rejoice in their 'spiritual' beauty, with their bodies enjoying seductive offerings without succumbing to the realisation of their desire? Whatever the answer to this question, Foucault missed the point when he huddled the experiencing virgins of the 3rd century with the self-investigating monks of the 4th century in order to distill a common trait, that of self-analysis. Finally: could 'beautiful boys' truly be transposed onto 'female virgins' without serious sexual-discursive complications? And could Methodius' ideal of virginity in any way be understood independent of his understanding of the 'resurrection of the body', with the integrity of its (virginised) sexual desire intact? These are among Patrick Vandermeersch's valid and challenging questions to both Foucault and his contemporary readership.

\section{Acknowledgements}

The author is an associate of the Center for the History of Philosophy and Science (CHPS), Radboud University Nijmegen, the Netherlands.

\section{Competing interests}

The author declares that he has no financial or personal relationships that may have inappropriately influenced him in writing this article.

\section{Author's contributions}

J.B. is the sole author of this article.

\section{Ethical considerations}

This article followed all ethical standards for research without direct contact with human or animal subjects.

\section{Funding information}

This research received no specific grant from any funding agency in the public, commercial or not-for-profit sectors.

\section{Data availability}

Data sharing is not applicable to this article as no new data were created or analysed in this study.

\section{Disclaimer}

The views and opinions expressed in this article are those of the author and do not necessarily reflect the official policy or position of any affiliated agency of the author.

\section{References}

Behr, J., 1993, 'Shifting sands: Foucault Brown and the framework of Christian asceticism', The Heythrop Journal 34(1), 1-21. https://doi. org/10.1111/j.1468-2265.1993.tb00902.x

Bernauer, J., 2021, 'Fascinating flesh: Revealing the spiritual Foucault', in recorded presentation delivered at the international conference Foucault's confessions on 04 May 2021, hosted and funded by the Department of Religion, Rice University, Houston, TX, with the support of the Rockwell Fund, viewed 30 May 2021, from https://foucaultsconfessions.org/.

Beukes, J., 2019, “"Foucault se sodomiet": Damianus se Liber gomorrhianus (1049) heropen', HTS Teologiese Studies/Theological Studies 75(4), a5216. https://doi. org/10.4102/hts.v75i4.5216

Beukes, J., 2020a, 'Histoire de la sexualité "4" (Les aveux de la chair): Aantekeninge vanuit die Nederlandse Foucault-navorsing', Verbum et Ecclesia 41(1), a2078. https://doi.org/10.4102/ve.v41i1.2078

Beukes, J., 2020b, Foucault in Iran, 1978-1979, AOSIS, Cape Town.

Beukes, J., 2020c, 'Intervroulike seksualiteit in die latere Middeleeue: 'n Ideëhistoriese oorsig', Verbum et Ecclesia 41(1), a2074. https://doi.org/10.4102/ve.v41i1.2074

Beukes, J., 2021a, 'Augustinus en vroulike homoërotiek in die vroeë Middeleeue: 'n Foucaultiaanse ideëhistoriese interpretasie', HTS Teologiese Studies/Theological Studies 77(4), a6880. https://doi.org/10.4102/hts.v77i4.6880

Beukes, J., 2021b, 'Raptus en die "vorm van die wil": 'n transgressiewe lesing van Foucault se Augustinus-interpretasie in Les aveux de la chair', Verbum et Ecclesia 42(1), a2310. https://doi.org/10.4102/ve.v42i1.2310

Beukes, J., 2022, 'Die ontwikkeling en komplekse samehange van die huidige vier bande in Foucault se Histoire de la sexualité', Tydskrif vir Geesteswetenskappe 61(4) (in publication).

Bonwetsch, G.N., 1891, Methodius von Olympus, vol. I. Schriften, Deichert, Erlangen.

Bonwetsch, G.N., 1903, 'Die Theologie des Methodius von Olympus', in Abhandlungen der königlichen Gesellschaft der Wisssenschaften zu Gottingen, Band VII(1), pp. 1-173, Weidmannsche Buchhandlung, Berlin.

Bonwetsch, G.N., 1917, 'De resurrectione', in G.N. Bonwetsch (ed., transl. \& comm.), Methodius, Herausgegeben im Auftrage der Kirchenväter-Commission, Der Königl. Preussischen Akademie der Wissenschaften, pp. 217-424, J.C. Hinrichs Buchhandlung, Leipzig.

Bracht, K., 1999, Volkommenheit und Vollendung: Zur Anthropologie des Methodius von Olympus, Mohr Siebeck, Tübingen.

Bracht, K. (ed.) 2017a, Methodius of Olympus: State of the art and new perspectives, Walter de Gruyter, Berlin

Bracht, K., 2017b, 'Methodius of Olympus: State of the art and new perspectives Introduction', in K. Bracht (ed.), Methodius of Olympus: State of the art and new perspectives, pp. 1-17, Walter de Gruyter, Berlin.

Bracht, K., 2017c, 'Eros as chastity: Transformation of a myth in the symposium of Methodius of Olympus', in K. Bracht (ed.), Methodius of Olympus: State of the art and new perspectives, pp. 38-62, Walter de Gruyter, Berlin.

Bril, A., 2006, 'Plato and the sympotic form in the sympoisum of St. Methodius of Olympus', Zeitschrift für antikes Christentum 9(1), 279-302. https://doi. org/10.1515/ZACH.2005.003

Brown, P., 2018, 'Il ne fut pas le mauvais génie puritain de l'Occident', L'Histoire 448(6), 35-36.

Brown, P., 2021, 'A conversation', in recorded presentation delivered at the international conference Foucault's confessions on 06 May 2021, hosted and funded by the Department of Religion, Rice University, Houston, TX, with the support of the Rockwell Fund, viewed 30 May 2021, from https:// foucaultsconfessions.org/. 
Cameron, A., 1986, 'Redrawing the map: Early Christian territory after Foucault', The Journal of Roman Studies 76, 266-271. https://doi.org/10.2307/300375

Chevallier, P., 2021, 'The birth of confessions of the flesh', in recorded presentation delivered at the international conference Foucault's confessions on 11 May 2021 hosted and funded by the Department of Religion, Rice University, Houston, TX with the support of the Rockwell Fund, viewed 30 May 2021, from https:// foucaultsconfessions.org/.

Clark, E.A., 1988, 'Foucault, the fathers and sex', Journal of the American Academy of Religion 56(4), 619-641. https://doi.org/10.1093/jaarel/LVI.4.619

Clark, E.A., 2021, 'Contextualizing Foucault's Augustine', in recorded presentation delivered at the international conference Foucault's confessions on 20 May 2021, hosted and funded by the Department of Religion, Rice University, Houston, TX with the support of the Rockwell Fund, viewed 30 May 2021, from https:// foucaultsconfessions.org/.

Clements, N.K., 2021a, 'Foucault's Christianities', Journal of the American Academy of Religion 89(1), 1-40. https://doi.org/10.1093/jaarel/lfab024

Clements, N.K., 2021b, 'Foucault's Christianities', in recorded presentation delivered at the international conference Foucault's confessions on 19 May 2021, hosted and funded by the Department of Religion, Rice University, Houston, TX, with the support of the Rockwell Fund, viewed 30 May 2021, from https:// foucaultsconfessions.org/.

Clements, N.K., 2021c, Foucault the confessor (forthcoming)

De Kesel, M., 2021, 'Van lust naar verlangen en terug: Over Michel Foucault, Bekentenissen van het vlees', Unpublished presentation delivered at a colloquium of the society Foucault Cirkel Nederland/België on 24 September 2021, organised by the Titus Brandsma Institute, Radboud University Nijmegen, Nijmegen.

De Wet, C.L., 2020, “\#“Le devoir des époux”: Michel Foucault's reading of John Chrysostom's marital ethic in Histoire de la sexualité 4: Les aveux de la chair ([1982-1984] 2018)', Religion and Theology 27(1-2), 114-151. https://doi. org/10.1163/15743012-bja10003

Dorrestijn, S., 2019, 'Confessions of the flesh finally published: A project with breaks and loose ends', Unpublished presentation delivered at a colloquium of the society Foucault Cirkel Nederland/Belgie on 12 December 2019, organised by the Department of Philosophy, University of Amsterdam, Amsterdam, pp. 1-2; with Addendum: 'Postume publicatie van Michel Foucaults Bekentenissen van het vlees', pp. 3-4.

Dorrestijn, S., 2021, 'Omgaan met technologie als verleider: Subjectivering en macht in een technologische kultuur', Unpublished presentation delivered at a colloquium of the society Foucault Cirkel Nederland/België on 24 September 2021, organised by the Titus Brandsma Institute, Radboud University Nijmegen, Nijmegen.

Elden, S., 2016, Foucault's last decade, Polity Press, Cambridge.

Elden, S., 2018, 'Review: Michel Foucault, Histoire de la sexualité 4: Les aveux de la chair', Theory, Culture and Society 35(7-8), 293-311. https://doi. org/10.1177/0263276418800206

Ewald, F., Fontana, A., Marchetti, V. \& Salomoni, A. (eds.), 1999, Michel Foucault. Les anormaux. Cours au collège de France 1974-1975, Seuil/Gallimard, Paris.

Ewald, F., Fontana, A. \& Senellart, M. (eds.), 2004, Michel Foucault. Sécurité, Territoire Population. Cours au Collège de France, 1977-1978, Seuil/Gallimard, Paris.

Ewald, F., Fontana, A. \& Senellart, M. (eds.), 2012, Michel Foucault. Du gouvernement des Vivants. Cours au Collège de France, 1979-1980, Seuil/Gallimard, Paris.

Farges, J., 1929, Les idée morales et religieuses de Méthode d'Olympe. Contribution à l'étude des rapports du Christianisme et de l'Hellénisme à la fin du troisième siècle Bibliothèque des archives de philosophie, Bauchesne, Paris.

Foucault, M., 1976 (English translation 1978), Histoire de la sexualité 1: La volonté de savoir, Collection Bibliothèque des Histoires, (Éditions) Gallimard, Paris (The history of sexuality, volume 1: The will to knowledge, transl. R. Hurley, Pantheon, New York, NY).

Foucault, M., 1984a (English translation 1985), Histoire de la sexualité 2: L'usage des plaisirs, Collection Bibliothèque des Histoires, (Éditions) Gallimard, Paris (The history of sexuality, volume 2: The use of pleasure, transl. R. Hurley, Random history of sexuality, volur
House, New York, NY).

Foucault, M., 1984b (English translation 1986), Histoire de la sexualité 3: Le souci de soi, Collection Bibliothèque des Histoires, (Éditions) Gallimard, Paris (The history of sexuality, volume 3: The care of the Self, transl. R. Hurley, Pantheon, New York, NY).

Foucault, M., 2018 (English translation 2021), Histoire de la sexualité 4: Les aveux de la chair, in F. Gros (ed.), Michel Foucault, Histoire de la sexualité 4: Les aveux de la chair, Collection Bibliothèque des Histoires, (Éditions) Gallimard, Paris (The chair, Collection Bibliothèue des Histoires, (Editions) Gallimard, Paris (The
history of sexuality, volume 4: Confessions of the flesh, transl. R. Hurley, Pantheon, history of sexuality

Goldhill, S., 1995, Foucault's virginity: Ancient erotic fiction and the history of sexuality, Cambridge University Press, Cambridge.

Gros, F., 2021, 'Foreword', in M. Foucault (ed.), The history of sexuality, volume 4 Confessions of the flesh, pp. vii-xiii, transl. R. Hurley, Pantheon, New York, NY.

Gros, F. (ed.), 2018, Michel Foucault, Histoire de la sexualité 4: Les aveux de la chair, Collection Bibliothèque des Histoires, (Éditions) Gallimard, Paris.

Holierhoek, J. (transl.), 2017, Geschiedenis van de seksualiteit I-III, Boom Uitgeverij, Amsterdam.

Holierhoek, J. (transl.), 2020, Bekentenissen van het vlees. Geschiedenis van de seksualiteit IV, Boom Uitgeverij, Amsterdam.

Howatson, M.C. \& Sheffield, F.C.C. (eds.), 2008, Plato: The symposium, transl. M.C. Howatson, Cambridge University Press, Cambridge.
Huffer, L., 2021, 'Foucault's queer virgins', in recorded presentation delivered at the international conference Foucault's confessions on 18 May 2021, hosted and funded by the Department of Religion, Rice University, Houston, TX, with the support of the Rockwell Fund, viewed 30 May 2021, from https:// support of the Rockwell
foucaultsconfessions.org/.

Hughes, A.B., 2017, 'Agency, restraint and desire: Virginity and Christology in Methodius of Olympus', in K. Bracht (ed.), Methodius of Olympus: State of the art and new perspectives, pp. 85-102, Walter de Gruyter, Berlin.

Huijer, M., 2021, 'Seks is saai: Vroegchristelijke versus moderne seksuele of the society Foucault Cirkel Nederland/België on 24 September 2021, organised by the Titus Brandsma Institute, Radboud University Nijmegen, Nijmegen.

Hurley, R. (transl.), 2021, Michel Foucault: The history of sexuality, volume 4: Confessions of the flesh, Pantheon, New York, NY.

Jordan, M., 2021, 'Lust in paradise: On the origins of sexualised selves', in recorded presentation delivered at the international conference Foucault's confessions on 13 May 2021, hosted and funded by the Department of Religion, Rice University, Houston, TX, with the support of the Rockwell Fund, viewed 30 May 2021, from https://foucaultsconfessions.org/.

Karskens, M., 2012, Michel Foucault, Boom Uitgeverij, Amsterdam.

Karskens, M., 2019, 'Kritische studie. Het regime van de bekentenissen: Foucaults Histoire de la sexualité 4: Les aveux de la chair', Tijdschrift voor Filosofie 81(3), 559-581.

Karskens, M., 2021, 'De religieuze codering van spiritualiteit: Martelaarschap en zelfoffer', Unpublished presentation delivered at a colloquium of the society Foucault Cirkel Nederland/België on 12 March 2021, organised by the Titus Brandsma Institute, Radboud University Nijmegen, Nijmegen.

Kessler, R. \& Vandermeersch, P.M.G.P., 2001, God, biblical stories and psychoanalytic understanding, Peter Lang Publishers, Brussels.

Klinkenberg, P., Hoeks, H., Boekraad, H.C. \& Van Dorsselaer, K. (transl.), 1984-1985, Michel Foucault: Geschiedenis van de seksualiteit I-III, SUN, Nijmegen.

LaValle Norman, D., 2017, 'Coming too late to the table: Methodius in the context of sympotic literary development', in K. Bracht (ed.), Methodius of Olympus: State of sympotic literary development', in K. Bracht (ed.), Methodius of Olymp
the art and new perspectives, pp. 18-37, Walter de Gruyter, Berlin.

Leezenberg, M., 2018a, 'Foucaults Les aveux de la chair: Een eerste bespreking', pp. 1-5, viewed 14 May 2021, from https://www.academia.edu/35977814/ Foucaults_Les_aveux_de_la_chair_Een_eerste_bespreking.

Leezenberg, M., 2018b, 'Foucault, seks en Augustinus', De Nederlandse Boekengids, April - May 2018, pp. 6-7.

Leezenberg, M., 2019, 'Foucault's 1960's lectures on sexuality: Deux cours inédits de Michel Foucault sur la sexualité (2018)', Unpublished presentation delivered at a colloquium of the society Foucault Cirkel Nederland/België on 12 December 2019, organised by the Department of Philosophy, University of Amsterdam, Amsterdam.

Leezenberg, M., 2021, 'Van Geert Grote tot Ignatius van Loyola: Seks, spiritualiteit en gouvernmentaliteit in de Late Middeleeuwen', Unpublished presentation delivered at a colloquium of the society Foucault Cirkel Nederland/België on 21 May 2021, organised by the Titus Brandsma Institute, Radboud University Nijmegen, Nijmegen.

Lorenzini, D., 2021, 'Foucault's genealogy of modern knowledge about sexuality: From São Paulo to Confessions of the Flesh', in recorded presentation delivered at the
international conference Foucault's confessions on 25 May 2021, hosted and funded international conference Foucault's confessions on 25 May 2021, hosted and funded
by the Department of Religion, Rice University, Houston, TX, with the support of the by the Department of Religion, Rice University, Houston, TX, with the support
Rockwell Fund, viewed 30 May 2021 from https://foucaultsconfessions.org/.

Massot, M.-L., Sforzini, A. \& Ventresque, V., 2018, 'Transcribing Foucault's handwriting with Transkribus', Foucault Fiches de Lecture, 06 November 2018, pp. 1-12, viewed
25 May 2021, from https://hal.archives-ouvertes.fr/hal-01913435v1/document.

Mejzner, M. \& Zorzi, M.B. (intr. \& transl.), 2010, Metodio di Olimpo. La risurrezione, Collana di testi patristici 216, Città Nuova Editrice, Rome.

Morrissey, S., 2018, 'Loneliness remembers what happiness forgets', Track 8, Californic Son, Étienne/BMG, LA, viewed 30 May 2021, from https://youtu.be/Za26VEYgz24.

Musurillo, H. \& Debidour, V.-H. (intr., transl. \& comm.), 1963, Le Banquet, sources Chretiennes (No. 95), Cerf, Paris.

Patterson, L.G., 1997, Methodius of Olympus: Divine sovereignty, human freedom and life in Christ, The Catholic University of America Press, Washington, DC.

Praet, D., 2020, 'Augustine of Hippo and Michel Foucault's history of sexuality', in A. Dupont, W. François \& J. Leemans (eds.), Nos sumus tempora: Studies on Augustine and his reception offered to Mathijs Lamberigts, pp. 213-236, Peeters, Augustine
Leuven.

Praet, D., 2021, 'Pastorale macht en zelf-tegnieken: Foucault en de ascese van de Woestijnvaders', Unpublished presentation delivered at a colloquium of the society Foucault Cirkel Nederland/België on 21 May 2021, organised by the Titus Brandsma Institute, Radboud University Nijmegen, Nijmegen.

Quasten, J.C. \& Plumpe, J. (transl.), 1958, The symposium: A treatise on chastity, ancient Christian writers, the works of the fathers in translation, The Newman Press, Westminster, MD.

Raffnsøe, S., 2018, 'Michel Foucault's confessions of the flesh: The fourth volume of the history of sexuality', Foucault Studies 25(1), 393-421. https://doi. org/10.22439/fs.v0i25.5593

Schaff, P. (ed.), 1885, 'The banquet of the ten virgins, or, concerning chastity', in AnteNicene fathers 6, the fathers of the third century, Methodius, pp. 513-599, Christian Classics Ethereal Library, Grand Rapids, MI, viewed 04 June 2021, from http://www.ccel.org/ccel/schaff/anf06.html.

Sforzini, A., 2021, 'Rebellious flesh: Virgins, consecrated flesh and the radicality of conversion', in recorded presentation delivered at the international conference
Foucault's confessions on 25 May 2021, hosted and funded by the Department of Foucault's confessions on 25 May 2021, hosted and funded by the Department of
Religion, Rice University, Houston, TX, with the support of the Rockwell Fund, viewed 30 May 2021, from https://foucaultsconfessions.org/. 
Treiber, G., 2019, 'Back to madness: The return of the early Foucault and future publications', Unpublished presentation delivered at a colloquium of the society Foucault Cirkel Nederland/België on 12 December 2019, organised by the Department of Philosophy, University of Amsterdam, Amsterdam.

Vandermeersch, P.M.G.P., 1975, 'Introversion, autoérotisme et autisme. Quelques notes historiques sur trois concepts apparentés', Revue de Psychologie et des Sciences de l'Éducation 10(1), 314-315.

Vandermeersch, P.M.G.P., 1976, 'De bekoring van de ethische stellingname. Een psychoanalytische bijdrage tot de ethica', Tijdschrift voor Theologie 16(1), 162-182.

Vandermeersch, P.M.G.P., 1978, Het gekke verlangen: Psychoterapie en ethiek, Dekker $\&$ Van de Vegt, Nijmegen.

Vandermeersch, P.M.G.P., 1979, 'De religie en het ontstaan van de psychiatrie. Rond de relatie tussen theologie en de wetenschappen van de psychè', Tijdschrift voor Theologie 19(1), 329-351, Reprints in 1980, Maandblad geestelik volksgezondheid 35(1), pp. 1088-1110; Binneveld, E.A. (ed.) 1982, Een psychiatrisch verleden. Uit die geschiedenis van de psychiatrie, pp. 64-93, Ambo, Baarn \& Vandermeersch (2016:17-58)

Vandermeersch, P.M.G.P., 1980, 'A. Vergote's "Bekentenis en Begeerte in de religie"\#', Tijdschrift voor Liturgie 64(1), 252-259.

Vandermeersch, P.M.G.P., 1982a, 'Het Narcisme: De psychoanalytische theorie en haar lotgevallen', in J.A. Huijts (ed.), Ik zei de gek. Tussen zelf-ontkenning en zelfverheerlijking, pp. 32-58, Ambo, Baarn.

Vandermeersch, P.M.G.P., 1982b, 'La religion et l'attachement à l'autorité', Le Supplément 138(1), 311-331.

Vandermeersch, P.M.G.P., 1984, Psychiatrie, godsdienst en gezag. De ontstaansgeschiedenis van de psychiatrie in België als paradigma, Acco, Louvain.

Vandermeersch, P.M.G.P., 1985a, 'S.A. Tissot en de strijd tegen het onanisme: Mythe of realiteit', in Documentatieblad Werkgroep Achttiende Eeuw 65-66, pp. 173-193, viewed 27 May 2021, from https://pure.rug.nl/ws/portalfiles/portal/121689502/ PVDM072Tissot.pdf.

Vandermeersch, P.M.G.P., 1985b, 'Médecins et congrégrations religieuses en Belgique: Les distributions du transfert dan le traitement moral', in Communication faite au Troisième colloque de la Société Internationale d'Historie de la Psychiatrie et de la Psychanalyse, tenu à Caen, à l’Hôpital du Bon Sauveur en 1985, pp. 1-10.

Vandermeersch, P.M.G.P., 1985c, 'Michel Foucault: Een onverwachte hermeneutiek van het christendom?', Tijdschrift voor Theologie 25(1), 250-277, viewed 26 May 2021 from https://pure.rug.nl/ws/portalfiles/portal/14438139/PVDM078_foucault.pdf.

Vandermeersch, P.M.G.P., 1987, Ethiek tussen wetenschap en ideologie, Uitgeverij Peeters, Louvain, viewed 26 May 2021, from https://research.rug.nl/en/ publications/ethiek-tussen-wetenschap-en-ideologie.

Vandermeersch, P.M.G.P., 1988, Passie en Beschouwing: De christelijke invloed op he westerse mensbeeld, Uitgeverij Peeters, Louvain.

Vandermeersch, P.M.G.P., 1989, 'Scepticisme als vorm van geloof', Wijsgerig Perspectief op Maatschappij en Wetenschap 30(1), 102-108, Reprint in Vandermeersch (2016:149-164).

Vandermeersch, P.M.G.P., 1990a, 'A cultural sexuality or a sexual culture?', in F. Van de Vijver \& G. Hutschemaekers (eds.), The investigation of culture: Current issues in cultural psychology, pp. 43-58, Tilburg University Press, Tilburg.

Vandermeersch, P.M.G.P., 1990b, 'Met elegantie, met fallocratie of met de dekmantel? Het ethische discours van de psychoanalyst', Psychoanalytische Perspectieven 14(1), 39-43.

Vandermeersch, P.M.G.P., 1990c, 'De volle waarheid van het verleden', De Psycholoog - Maandblad Nederlands Instituut van Psychologen 25(1), 274-276.

Vandermeersch, P.M.G.P., 1991a, Unresolved questions in the Freud/Jung Debate: On psychosis, sexual identity and religion, transl. A. Marivoet \& V. Sansone, Leuven University Press, Louvain.

Vandermeersch, P.M.G.P., 1991b, 'Psychotherapeutische en religieuze rituelen', Rekenschap 38(1), 24-33, Reprints in Werkmap voor Liturgie 25(1), 79-91 \& Vandermeersch (2016:59-80).

Vandermeersch, P.M.G.P., 1991c, 'The victory of psychiatry over demonology: The origin of the nineteenth-century myth', History of Psychiatry 2(8), 351-363. https://doi.org/10.1177/0957154X9100200801

Vandermeersch, P.M.G.P., 1992a, 'Heymans' panpsychische hoop: Honderd jaa vervreemding van de grond der dingen', De Psycholoog - Maandblad Nederland Instituut van Psychologen 27(10), 437-440.

Vandermeersch, P.M.G.P., 1992b, 'Moraliseren met de natuur als dekmantel', in K. Merkx (ed.), Sociaal-etische aspecten van waarachtigheid en leugen, pp. 45-62, Ambo, Baarn.

Vandermeersch, P.M.G.P., 1992c, 'Pastoral relationship and sexual issues', in J.H.N. Kerssemakers (ed.), Sex and religion: Religious issues in sexological treatment, sexological issues in pastoral care, proceedings of the First Major conference on the relationship between sex and religion on the 10th World

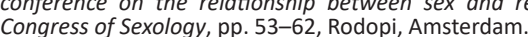

Vandermeersch, P.M.G.P., 1992d, Over psychose, seksualiteit en religie: Het debat tussen Freud en Jung, SUN, Nijmegen.

Vandermeersch, P.M.G.P., 1993, 'De perversie: Het natuurlijke complement van neurose en psychose in de godsdienstpsyschologie?', in H. Zock (ed.), Geloven tussen waan en werkelijkheid, pp. 37-52, De Ploeg, Maarssen.

Vandermeersch, P.M.G.P., 1995, 'Du bon usage de la flagellation, et des problèmes posés par son interprétation', Religiologiques 12(1), 215-242.

Vandermeersch, P.M.G.P., 1996a, 'Hooglerarenmoraal: De wijnschenker en de pentiumprofessor', in G. Hutschemaekers \& M. De Winter (eds.), De veranderlijke moraal: Over moraliteit en psychologie, pp. 217-234, SUN, Nijmegen.
Vandermeersch, P.M.G.P., 1996b, 'Uit de hemel gevallen? De levensbeschouwing van de geestelijke gezondheidzorg' Trimboslezing Nederlands Centrum Geestelijke Volksgezondheid, Utrecht, pp. 1-24, viewed 27 May 2021, from https://pure.rug. Volksgezondheid, Utrecht, pp. 1-24, viewed 27 May 2021,
nl/ws/portalfiles/portal/121515213/PVDM162Trimbos.pdf.

Vandermeersch, P.M.G.P., 1996c, 'Hartstochten en deugden', in K.-W. Merks \& F.J.H. Vosman (eds.), Uit op geluk. Die Katechismus van de katholieke kerk over goed en kwaad. Uitleg en commentaar, pp. 99-119, Gooi en Sticht, Baarn.

Vandermeersch, P.M.G.P., 1997, 'Zur Bedeutung von Michel Foucault für die heutige Psychiatrie', Fundamenta Psychiatrica 1(1), 141-146.

Vandermeersch, P.M.G.P., 1998a, 'Met de voeten in het water. Bedenkingen van een psychoanalyticus bij de zondvloedverhalen', Tijdschrift voor Theologie 38(1), 50-70, English translation in F. Garcia Martinez \& G. Luttikhuizen (eds.) 1998, Interpretation of the flood (Themes in biblical narratives: The Jewish and Christian Tradition, nr. 1) pp. 167-193, Brill, Leiden. See also Vandermeersch (1998b).

Vandermeersch, P.M.G.P., 1998b, 'Et si, finalement, ça pissait seulement dru? Les réflexions d'un psychanalyste au sujet du Déluge', Revue Européene d'Anthropologie Littéraire 3(1), 21-53.

Vandermeersch, P.M.G.P., 1998c, 'Het taboe van het echt gebeurde feit. De analyse van de eindeloze als aanleiding tot de psychoanalytische studie van de godsdienstwetenschap', in J. Baneke \& R. Pierloot (eds.), Psychoanalyse en Anthropologie, pp. 31-56, Thela Thesis, Amsterdam.

Vandermeersch, P.M.G.P., 1999a, Flarden. Geestelijke verzorging in het verpleeghuis, Boekencentrum, Zoetermeer.

Vandermeersch, P.M.G.P., 1999b, 'Revolte, kennis en overdracht', Psychologie en Maatschappij 23(1), 345-354.

Vandermeersch, P.M.G.P., 1999c, 'De opstandige hartstocht', in R. Hoozee, J. Tollebeek \& T. Verschaffel (eds.), Mise-en-scène. Keizer Karel en de verbeelding van de negentiende eeuw, pp. 250-253, Mercatorfonds, Antwerp.

Vandermeersch, P.M.G.P., 2000, 'Lust in Christianity', Unpublished presentation delivered at a colloquium of the Wijsgerig Gezelschap on 25 March 2000, Louvain pp. 1-13, viewed 29 May 2021, from https://patrickvandermeersch.org/2000lust-in-het-christendom/.

Vandermeersch, P.M.G.P., 2002, La chair de la Passion. Une histoire de foi: La flagellation, Cerf, Paris.

Vandermeersch, P.M.G.P., 2004, Carne de la Pasión, Trotta, Madrid.

Vandermeersch, P.M.G.P., 2008, 'Self-flagellation in the early modern era', in J.F. Van Dijkhuizen \& K. Enenkel (eds.), The sense of suffering: Constructions of physical pain in early modern culture, pp. 261-273, Brill, Leiden.

Vandermeersch, P.M.G.P., 2011, 'Juridische fictie ten dienst van de ware liefde', in $H$. Warnink (ed.), Quid est veritas? Over Kerkelijk Huwelijksrecht en Waarheid, pp. 73-83, Peeters, Louvain.

Vandermeersch, P.M.G.P., 2014, 'Van Freud naar gender: Wisselende sociale visies op seksualiteit', Speling, Tijdschrift voor Bezinning 66(1), 19-24.

Vandermeersch, P.M.G.P., 2016, Scepticisme als vorm van geloof. Beschouwingen van een godsdienstpsycholoog, KSGV, Tilburg.

Vandermeersch, P.M.G.P., 2017a, 'The confessing animal: Michel Foucault's fascination with confession, and gender's longing for the saving pleasures of the body', Unpublished presentation delivered at a colloquium, The Ambiguity of Transparency, of the Royal Flemish Academy of Belgium for Science and the Arts (KVAB), 11-12 December 2017, pp. 1-21, viewed 29 May 2021, from https:// patrickvandermeersch.org/2017-foucault-and-christianity/.

Vandermeersch, P.M.G.P., 2017b, 'The mystery of the erased sentence in Freud's three essays on the theory of sexuality', in P. Van Haute \& H. Westerink (eds.), Deconstructing normativity? re-reading Freud's three essays, pp. 55-63, Routledge, London.

Vandermeersch, P.M.G.P., 2020, Laïcite, théologie et sainte ignorance: Histoire d'une mésente, Religions Christianisme Sciences Politiques. Éditions L'Harmattan, Paris.

Vandermeersch, P.M.G.P., 2021, 'Michel Foucault en Methodius van Olympus', Unpublished presentation delivered at a colloquium of the society Foucault Cirkel Nederland/België on 12 March 2021, organised by the Titus Brandsma Institute, Radboud University Nijmegen, Nijmegen, pp. 1-20, viewed 09 April 2021, from https://patrickvandermeersch.org/2021-michel-foucault-leest-methodius-vanolympus/, Permission for extensive referencing to and paraphrasing this pape (including the translation of a substantial part of its contents from Dutch to English) was requested on 09 April 2021 and granted on the same date.

Vandermeersch, P.M.G.P. \& Westerink, H., 2007, Godsdienstpsychologie in cultuurhistorisch perspectief, Boom Uitgeverij, Amsterdam.

Van Rooden, A., 2019, 'Some remarks on Folie, langage, littérature (2019)', Unpublished presentation delivered at a colloquium of the society Foucault Cirke Nederland/België on 12 December 2019, organised by the Department of Philosophy, University of Amsterdam, Amsterdam.

Van Ussel, J., 1968, De geschiedenis van het sexuele probleem, Boom, Meppel.

Waterfield, R., 2002, 'Introduction', in (intr. \& transl.), R. Waterfield, Plato, Phaedrus, pp. ix-xlix, Oxford University Press, Oxford.

Waterfield, R. (intr. \& transl.), 2002, Plato, Phaedrus, Oxford University Press, Oxford.

Westerink, H., 2019a, De lichamen en hun lusten. In het spoor van Foucaults 'Geschiedenis van de seksualiteit', Uitgeverij Vantilt, Nijmegen.

Westerink, H., 2019b, 'Henri Bremond and the religious experience in context', Interdisciplinary Journal for Religion and Transformation in Contemporary Society 5(1), 33-51. https://doi.org/10.30965/23642807-00501003

Westerink, H., 2021, 'Augustinus, Cassianus en het probleem van de libido', Unpublished presentation delivered at a colloquium of the society Foucault Cirke Nederland/België on 12 March 2021, organised by the Titus Brandsma Institute, Radboud University Nijmegen, Nijmegen. 